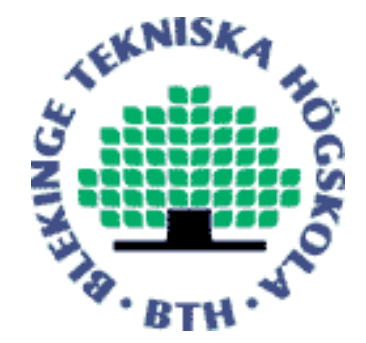

Copyright (C) 2012 IEEE.

Citation for the published paper:

Techno-Economic Analysis of UMTS900 and UMTS2100 for Rural Connectivity in Tanzania

Fatuma Simba, Lena Trojer, Nerey Mvungi, Bakari Mwinyiwiwa, Emmanuel Mjema

14th IEEE International Conference on Communication Technology (ICCT)

2012 Chengdu, China

This material is posted here with permission of the IEEE. Such permission of the IEEE does not in any way imply IEEE endorsement of any of BTH's products or services Internal or personal use of this material is permitted. However, permission to reprint/republish this material for advertising or promotional purposes or for creating new collective works for resale or redistribution must be obtained from the IEEE by sending a blank email message to pubs-permissions@iee.org.

By choosing to view this document, you agree to all provisions of the copyright laws protecting it. 


\section{Techno-economic Analysis of UMTS900 and UMTS2100 for Rural Connectivity in Tanzania}

\author{
Fatuma Simba, Lena Trojer \\ Blekinge Institute of Technology \\ Karlshamn, Sweden \\ fatuma.simba@bth.se \\ lena.trojer@bth.se
}

\author{
Bakari Mwinyiwiwa, Nerey Mvungi, Emmanuel \\ Mjema \\ University of Dar es Salaam \\ Dar es Salaam, Tanzania \\ bakarimwinyiwiwa@yahoo.com \\ nhmvungi@yahoo.com,emjema@yahoo.com
}

\begin{abstract}
Rural areas of the developing countries lack Information and Communication Technology (ICT) infrastructures such as access network, also known as last mile connectivity, to deliver ICT services. The lack of connectivity is due to high cost of implementing ICT infrastructures. Wireless technologies are envisioned as candidates for rural connectivity. They are not only easier and faster to deploy but also cheaper than the wired technologies. This paper presents a technoeconomic analysis of two wireless technologies in Tanzania, called third generation $(3 \mathrm{G})$ implemented at $900 \mathrm{MHz}$ and at $2100 \mathrm{MHz}$ frequency bands. Objectives of techno-economic analysis are to investigate economic feasibility and to determine a cost effective option between the two connectivity options. Results show that, $3 \mathrm{G}$ at $900 \mathrm{HMz}$ is a feasible and cost - effective connectivity technology in Tanzania. These results can be generalized to other developing countries, since rural areas pose similar characteristics with regard to ICT infrastructure development.
\end{abstract}

Keywords- Rural Areas, Techno-economic, UMTS.

\section{INTRODUCTION}

Rural areas, especially those of the developing countries pose challenges in implementing Information and Communication Technology (ICT) infrastructures such as connectivity. The challenges are due to the environments of the rural areas, which are characterized by scarce population, low income community and sometimes difficult topography such as mountains. These challenging characteristics make wireless technologies to become potential candidates for ICT infrastructures in rural areas. In the last decade, the world experienced a fast evolution of mobile wireless technologies from first generation $(1 \mathrm{G})$ to fourth generation $(4 \mathrm{G})$. The third generation $(3 \mathrm{G})$ and fourth generation $(4 \mathrm{G})$ of mobile wireless technologies have capabilities to offer broadband capacity and support to multimedia services, hence, they are envisioned as the potential solution for rural areas broadband connectivity needs.

However, the existing deployments of cellular mobile wireless technology, especially the $3 \mathrm{G}$ variants, are faced by coverage challenges. The widely deployed $3 \mathrm{G}$ systems are implemented at $2100 \mathrm{MHz}$ frequency band. At this high frequency, the radio waves propagation path loss is high, which results in a shorter distance coverage. Due to the mentioned challenges posed by rural areas, the $3 \mathrm{G}$ technologies are widely deployed in urban and city centers; this is a business strategy to tap a number of customers in small single area. Nevertheless, the coverage problem of $3 \mathrm{G}$ at $2100 \mathrm{MHz}$ network can be addressed by implementing third generation network at lower frequency band, where the radio waves propagation path loss is low, resulting into a long distance coverage. This is an emerging technique where $3 \mathrm{G}$ networks are implemented at $900 \mathrm{MHz}$ frequency band [1];[2]. This technique is widely used to provide 3G networks to rural areas. By March, 2011, there were 27 worldwide commercially deployed $3 \mathrm{G}$ networks at $900 \mathrm{MHz}$ frequency band [3]. The $3 \mathrm{G}$ at $900 \mathrm{MHz}$ networks can be implemented by re-using existing infrastructures of Global System for Mobile communication (GSM) base stations. Because $3 \mathrm{G}$ at $900 \mathrm{MHz}$ and $3 \mathrm{G}$ at $2100 \mathrm{MHz}$ networks are both wireless technologies with capabilities to support multimedia services to rural areas, then it has become necessary to compare the two technologies using economic criteria to identify their economic feasibility and determine a cost effective option between the two technologies.

The remainder of this paper is organized as follows: section II presents methodology used in this paper, which comprises of radio network dimensioning and techno-economic analysis. Results of the techno-economic analysis are presented in section III and section IV provides the conclusion.

\section{METHODOLOGY}

Radio network dimensioning and techno-economic analysis were the main methods used to investigate economic feasibility and to determine a cost effective option between $3 \mathrm{G}$ at $900 \mathrm{MHz}$ and $3 \mathrm{G}$ at $2100 \mathrm{MHz}$ networks. The radio network dimensioning is used to identify number of network equipment required to provide coverage of a given geographical area. Taking Tanzania as a case study, with a geographical area of about $945,087 \mathrm{~km}^{2}$ and assuming a coverage requirements of $80 \%$, the remaining $20 \%$ is assumed to be water bodies such as lakes and rivers, then a total area to be covered is $756,070 \mathrm{~km}^{2}$. Thereafter a techno-economic analysis is conducted which comprises of network cost analysis, networks comparison based on the Net Present Value (NPV), payback period and Internal Rate of Return (IRR) economic criteria, and finally sensitivity analysis is done to study impact of uncertainties and risks. The objective of network cost analysis is to identify the required network equipment and their respective costs in order 
to derive capital costs, operational costs and revenue for $3 \mathrm{G}$ mobile wireless networks.

\section{A. Radio Network Dimensioning}

Radio network dimensioning is performed to estimate number of sites (nodeBs) and Radio Network Controllers (RNCs) required to provide coverage to the $80 \%$ geographical area of Tanzania. In order to get the required number of sites, link budget calculation is done to estimate the maximum allowed propagation path loss for both the $3 \mathrm{G}$ Universal Mobile Telecommunication Systems (UMTS) at $900 \mathrm{MHz}$, referred to as UMTS900 and $3 \mathrm{G}$ UMTS at $2100 \mathrm{MHz}$, referred to as UMTS2100. Propagation path loss is the difference (in $\mathrm{dB}$ ) between the transmitted power and the received power. It represents signal level attenuation caused by free space propagation, reflection, diffraction and scattering [4];[5]. Link budget calculations were done based on $12.2 \mathrm{kbps}$ voice service for both UMTS900 and UMTS2100. The link budget for mobile wireless networks are usually calculated (dimensioned) based on voice service with the assumption that voice service is the key business of the mobile network operators [4];[6]. The parameter values for link budget calculation were taken from Holma and Toskala [4] for the UMTS2100 and values for UMTS900 were obtained from Ovum Consulting [7] as shown in table I.

TABLE I. LINK BUDGET CALCULATIONS BASED ON 12.2 KBPS VOICE SERVICE

\begin{tabular}{|c|c|c|c|}
\hline & \multicolumn{2}{|c|}{ Values } & \multirow[t]{2}{*}{ Formula } \\
\hline Transmitter (Mobile) & $\begin{array}{l}2100 \\
\text { MHz }\end{array}$ & $\begin{array}{l}900 \\
\mathrm{MHz}\end{array}$ & \\
\hline $\begin{array}{l}\text { Max. Mobile transmission } \\
\text { power }(\mathrm{w})\end{array}$ & 0.125 & 0.25 & \\
\hline $\begin{array}{l}\text { Max. Mobile transmission } \\
\text { power in } \mathrm{dBm}\end{array}$ & 21.0 & 24.0 & $\mathrm{a}$ \\
\hline Antenna Gain (dBi) & 0.0 & 2.0 & $\mathrm{~b}$ \\
\hline Body Loss $(\mathrm{dB})$ & 3.0 & 0.0 & $\mathrm{c}$ \\
\hline $\begin{array}{l}\text { Equivalent isotropic } \\
\text { Radiated power (EIRP) } \\
(\mathrm{dBm})\end{array}$ & 18.0 & 26.0 & $d=a+b-c$ \\
\hline \multicolumn{4}{|l|}{ Receiver (Base Station) } \\
\hline $\begin{array}{l}\text { Thermal noise density } \\
(\mathrm{dBm} / \mathrm{Hz})\end{array}$ & -174.0 & -174.0 & $\mathrm{e}$ \\
\hline $\begin{array}{l}\text { Base station receiver noise } \\
\text { figure }(\mathrm{dB})\end{array}$ & 5.0 & 5.0 & $\mathrm{f}$ \\
\hline $\begin{array}{l}\text { Receiver noise density } \\
(\mathrm{dBm} / \mathrm{Hz})\end{array}$ & -169.0 & -169.0 & $g=e+f$ \\
\hline $\begin{array}{l}\text { Receiver noise power } \\
(\mathrm{dBm})\end{array}$ & -103.2 & -103.2 & $\mathrm{~h}=\mathrm{g}+10^{*} \log (3840000)$ \\
\hline Interference margin (dB) & 3.0 & 3.0 & $\mathrm{i}$ \\
\hline $\begin{array}{l}\text { Total effective noise }+ \\
\text { interference }(\mathrm{dBm})\end{array}$ & -100.2 & -100.2 & $\mathrm{~J}=\mathrm{h}+\mathrm{i}$ \\
\hline Processing gain $(\mathrm{dB})$ & 25.0 & 25.0 & $\mathrm{k}=10 * \log (3840 / 12.2)$ \\
\hline $\begin{array}{l}\text { Required signal to noise } \\
\text { ratio } \mathrm{Eb} / \mathrm{No}(\mathrm{dB})\end{array}$ & 5.0 & 3.1 & 1 \\
\hline Receiver Sensitivity & -120.2 & -122.0 & $\mathrm{~m}=1-\mathrm{k}+\mathrm{j}$ \\
\hline $\begin{array}{l}\text { Base station antenna gain } \\
\text { (dBi) }\end{array}$ & 18.0 & 18.0 & $\mathrm{n}$ \\
\hline $\begin{array}{l}\text { Cable loss in the base } \\
\text { station }(\mathrm{dB})\end{array}$ & 2.0 & 2.0 & o \\
\hline Fast fading Margin (dB) & 0.0 & 5.0 & $\mathrm{p}$ \\
\hline Maximum path loss (dB) & 154.2 & 159.0 & $q=d-m+n-o-p$ \\
\hline Log-normal fading margin & 7.3 & 10.0 & $\mathrm{r}$ \\
\hline
\end{tabular}

\begin{tabular}{|l|l|l|l|}
\hline$(\mathrm{dB})$ & & & \\
\hline $\begin{array}{l}\text { Soft handover gain }(\mathrm{dB}), \\
\text { Multicell }\end{array}$ & 3.0 & 3.0 & $\mathrm{~s}$ \\
\hline In-car/indoor loss & 8.0 & 10.0 & $\mathrm{t}$ \\
\hline $\begin{array}{l}\text { Interference due to co- } \\
\text { location with GSM } \\
\text { 900MHz (dB) }\end{array}$ & 0 & 3 & $\mathrm{v}$ \\
\hline $\begin{array}{l}\text { Allowed Propagation } \\
\text { Loss (dB) }\end{array}$ & $\mathbf{1 4 1 . 9}$ & $\mathbf{1 3 9 . 0}$ & $\mathbf{u}=\mathbf{q}-\mathbf{r}+\mathbf{s}-\mathbf{t}-\mathbf{v}$ \\
\hline
\end{tabular}

The obtained propagation loss is used to estimate cell range by using the Cost 231 Hata radio propagation model [8];[9];[10]. A radio propagation model is an empirical mathematical formulation, which characterizes radio wave propagation as a function of frequency and distance, created with the goal of formalizing the way radio waves are propagated from one place to another. Such models typically predict the path loss along a link or the effective coverage area of a transmitter [8]. The obtained cell range is further used to calculate site area and the required number of sites to satisfy coverage requirement.

Considering the rural area which is a focus of this paper, the Cost 231 Hata propagation model equations for propagation path loss in decibel (dB) with corresponding correction factors for rural environment [10]; [7] as shown in equation (1) was used.

$$
\mathrm{L}(R)_{\text {rural }}=\mathrm{L}(R)_{\text {urban }}-4.78 \log ^{2}(f)+18.33 \log (f)-40.94
$$

for $f=920 \mathrm{MHz}$ (UMTS900)

$\mathrm{L}(R)_{\text {rural }}=35.2 \log (R)+98$

for $f=1950(\mathrm{UMTS} 2100)$

$\mathrm{L}(R)_{\text {rural }}=35.2 \log (R)+105$

where $\mathrm{f}=$ frequency

$\mathrm{L}(\mathrm{R})=$ maximum allowed propagation path loss $\mathrm{R}=$ Cell range

From the link budget calculations, the obtained values of the maximum allowed propagation path loss for UMTS900 and UMTS2 100 were $139.0 \mathrm{~dB}$ and $141.9 \mathrm{~dB}$ respectively. Then, the cell ranges for both UMTS900 and UMTS2100 are calculated by using equation (1).

$$
\begin{aligned}
& \text { for } f=920 \mathrm{MHz} \\
& \mathrm{L}(R)_{\text {rural }}=35.2 \log (R)+98 \\
& 139=35.2 \log (R)+98 \\
& \mathrm{R}=14.6 \mathrm{~km} \approx 15 \mathrm{~km} \\
& \text { for } f=1950 \\
& \mathrm{~L}(R)_{\text {rural }}=35.2 \log (R)+105 \\
& 141.9=35.2 \log (R)+105 \\
& \mathrm{R}=11.18 \mathrm{~km} \approx 11 \mathrm{~km}
\end{aligned}
$$

The cell range $\mathrm{R}$ is further used to calculate site area $(\mathrm{Sa})$, which is a function of the base station sectorization configuration [7]. Assuming three sectored antennas, the site 
coverage for UMTS900 and UMTS2100 were calculated by using equation (2).

$$
3 a=\frac{\sqrt[7]{3}}{8} R^{2}
$$

For UMTS900, where cell range, $\mathrm{R}=15 \mathrm{~km}$, the site area is $\mathrm{S}_{\mathrm{a}}=31.7 \mathrm{~km}^{2} \approx 32 \mathrm{~km}^{2}$

For UMTS2100, where cell range, $\mathrm{R}=11 \mathrm{~km}$, site area is $\mathrm{S}_{\mathrm{a}}=17 \mathrm{~km}^{2}$

Furthermore, the site coverage area was used to calculate number of sites required to fulfill a given geographical coverage requirement. The number of sites were calculated as a ratio of total area to be covered over the site coverage area. Assuming the coverage requirements of $80 \%$ of Tanzania, which is $756,070 \mathrm{~km}^{2}$. With the site area of $32 \mathrm{~km}^{2}$ and $17 \mathrm{~km}^{2}$ for UMTS900 and UMTS2100 respectively, their respective number of sites are given by using equation (3).

$$
\text { Number of Sttas }=\frac{\text { Tatal geagraph ical area }}{\text { Site covarage area }}
$$

$$
\text { Sites }_{900}=(756,070 / 32)=23,627
$$

$$
\text { Sites }_{2100}=(756,070 / 17)=44,474
$$

Number of the required RNCs were obtained by RNC dimensioning procedure. The purpose of RNC dimensioning is to find the number of RNCs needed to handle traffic offered by the estimated subscribers. Tanzania regulatory authority report a sum of $21,158,364$ voice subscribers and 462,514 mobile wireless internet subscribers [11]. Thus, total number of subscribers expected to be served by these networks is 462,514 $+21,158,364=21,620,878$. The following limitations on RNC capacity were taken into consideration, out of which the most demanding (which requires largest number of RNCs) was selected in the process of RNC dimensioning [5]:

$\begin{array}{cl}\text { i. } & \text { Maximum number of cells } \\ \text { ii. } & \text { Maximum number of BSs under one RNC } \\ \text { iii. } & \text { Maximum Iub throughput } \\ \text { iv. } & \text { Amount and type of interfaces. }\end{array}$

Therefore, through RNC dimensioning procedures, number of RNCs required for $80 \%$ coverage in Tanzania were calculated based on the constraints mentioned. The main focus of this paper is on the access network part, therefore it is assumed that costs and equipment for core networks part are the same in both cases and the operator has access to the core network, whether own or leased.

\section{B. Techno-economic Analysis}

Techno-economic analysis is defined as a systematic analysis with the aim to recognize opportunities and threats. It is a common method used to evaluate projects, taking into account the time value of money. The cash flow, discounted cash flow, NPV, IRR, payback period and sensitivity analysis are the economic criteria often used in techno-economic analysis [12].

\section{1) CAPEX, OPEX and Revenue Calculations}

The total costs of each connectivity technology is made up of initial investment costs called Capital Expenditure (CAPEX) and Operational Expenditure, abbreviated as OPEX. In this section, the value of CAPEX, OPEX and revenue were calculated, which will later be used for calculations of economic criteria in the techno-economic analysis. Capital cost is the first time investment cost in the network deployment. The capital costs sometimes are referred to as the initial investment which includes all the network equipment costs, installation and site rental charges. Network equipments costs, and other related activities such as sites acquisition costs are taken into consideration in order to derive annual CAPEX and OPEX costs. Operational costs are the recurring costs made up of network operational and maintenances costs. The value of OPEX was calculated as a twenty percent of the CAPEX costs. Values for equipment costs were taken from values of network equipment costs for the year 2011 forecasted by Ovum consulting [7]. Spectrum license fee and network facility service operation fee were obtained from Tanzania Regulatory Authority (TCRA) [13].

Revenue is defined as benefits generated by the investment. For communication network, it is assumed that revenue is generated by selling voice, short message services (sms) and internet-based services to individual and corporate customers. Number of customers in Tanzania that are subscribed to the mobile wireless internet services is 462,514 and voice subscribers are $21,158,364$, that add up to a total of $21,620,878$ subscribers for the mobile wireless network operators [11]. TCRA shows an annual revenue per user (ARPU) per month for sms and voice services of 5,849 Tanzanian shillings (TShs) [11], which approximates to \$6 ARPU/month. Therefore revenue generated from voice and sms services is $21,158,364 \mathrm{x}$ $\$ 6=\$ 126,950,184 /$ month. In one year, voice and sms service generate $\$ 126,950,184 \times 12=\$ 1,523,402,208$.

Taking an assumption that on average, corporate and individual users can buy $10 \mathrm{~GB}$ of internet bundle at $\$ 270$ per month for their internet related services (such as data, MMS, video, VoIP, etc). Then, revenue generated from mobile internet subscribers is 462,514 x $\$ 270=\$ 124,878,780 /$ month. For a year, mobile internet subscribers generate $\$ 124,878,780$ $\mathrm{x} 12=\$ 1,498,545,360$. In total, voice, sms and internet services generate $\$ 1,523,402,208+\$ 1,498,545,360$ $=\$ 3,021,947,568$ per year. It is worth to note that, the two connectivity options compared are required to provide coverage to the same size of a given geographical area. Therefore, it is expected that the total number of users served are the same for each technology and so is the total revenue generated.

Deployment of UMTS900 and UMTS2100 networks represent two different connectivity models suitable for broadband access networks. It is obvious that initial investment and operational costs are likely to vary between the two options. The following section aimed to provide the economic standpoint of each technology by using techno-economic analysis. Therefore, each technology is assessed according to 
three conventional economic criteria, NPV, IRR and payback period. Furthermore, sensitivity analysis is performed in order to study impact of uncertainties and risks. The main purpose of sensitivity analysis is to determine which are the important economic variables of a network and to what extent?

\section{2) Comparison based on NPV, Payback Period and IRR}

Net Present Value is the difference between an investment's market value and its costs (Ross et al., 2000). In other words, NPV can be defined as the future stream of benefits and costs converted into equivalent values today. This is done by assigning monetary values to benefits and costs, discounting future benefits and costs using an appropriate discount rate, and subtracting the sum of discounted costs from the sum of discounted benefits. NPV is an indicator of how much value an investment or project adds to the firm. An investment should be accepted if its NPV is positive and rejected if it is negative. The decision should be indifferent if the NPV is zero. This is because with zero NPV, it means the investment would neither gain nor lose value [12]. The NPV is calculated by using formula given in equation (4):

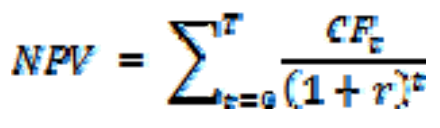

where,

$$
\begin{aligned}
& \mathrm{CF}_{\mathrm{t}}=\text { cash flow } \\
& \mathrm{r}=\text { discount rate } \\
& \mathrm{t}=\text { time, usually in years. }
\end{aligned}
$$

In this paper, the NPV is calculated as the sum of all the discounted cash flows during the economic life time of the network investment. The net cash outflow is the summation of capital and operational costs per year while the net cash inflow in a year is obtained after deduction of operational costs, depreciation charges and income taxes from the revenue.

A fixed asset is considered depreciable if it will wear out or become obsolete over the years of its life period. The life that is assigned to an item depends on industry standards, management standards, or governmental regulations. Depreciation is defined as an accounting methodology which allows an organization to spread the cost of a fixed asset over the expected useful life of that asset. At the end of each period of the useful life of the asset, a part of the cost is expensed. Depreciation expenses are calculated by using either a straight line depreciation method or an accelerated depreciation method. The straight line method calculates depreciation by spreading the cost evenly over the life of the fixed asset. Accelerated depreciation methods such as declining balance and sum of years digits, calculate depreciation by expensing a large part of the cost at the beginning of the life of the fixed asset [14];[15];[12].

In this paper, depreciation charges were calculated according to the straight-line method. Therefore, the depreciation cost of each asset was calculated by dividing the asset's cost by the number of years in the economic life time of the investment; five (5) years in this case. Income tax is usually charged after depreciation and operational costs have been deducted from the revenue. According to Tanzanian tax system, the income tax is charged at $30 \%$ of the revenues [16]. Then, the net cash inflow is what remains from the revenue after OPEX, depreciation and tax costs are deducted.

In calculating the NPVs, the value of discounted rate used was $10 \%$, which is the industry benchmark rate-of-return [12]. Five years is the assumed economic lifetime of the networks investment. Finally, NPV values were calculated by using equation (4).

Internal rate of return is defined as the discount rate that makes the NPV of an investment equal to zero. This rate is called the "internal" rate in the sense that it only depends on the cash flows of that particular investment, not on rates offered elsewhere [12]. Due to the fact that, the IRR of an investment is the required return that results in a zero NPV when used as the discount rate, then an investment is accepted if the IRR exceeds the required return, otherwise it should be rejected [12]. If the IRR is greater than the discount rate used for the project, then the investment is judged to be profitable. The IRR gives a good indication of the value achieved with respect to the value invested. Common methods to calculate IRR are by using financial calculators, Microsoft excel software or by manual trial and error calculations. The Microsoft excel software was used to calculate the IRR values in this paper.

\section{3) Sensitivity Analysis}

Sensitivity analysis is a way to predict the outcome of a decision if a situation turns out to be different compared to the key prediction(s). It is the investigation of what will happen to the key decision criteria, when one of the variables is changed. Sensitivity analysis is useful in pinpointing variables that deserve the most attention. It points out where forecasting errors will do most damage, but it is worth to note that it does not tell what to do with the errors [12].

The IRR is sensitive to (affected by) changes in capital and operational costs. However, IRR is least sensitive to changes in the economic lifetime of the investment. On the other hand, NPV is sensitive to economic lifetime of an investment, the discount rate as well as to changes in capital and operational costs. Variables that are likely to change and they affect both IRR and NPV economic criteria, are capital and operational costs. In this case, sensitivity analysis investigated separately the impact due to changes $(25 \%$ increase or decrease) in the capital costs and operational costs of the UMTS900.

\section{RESULTS}

TableII summarizes results of the radio network dimensioning (number of NodeBs and number of RNCs) for both UMTS900 and UMTS2100.

TABLE II. REQUIRED NUMBER OF SITES, NODEBS AND RNCS

\begin{tabular}{|l|l|l|}
\hline Equipment & UMTS $_{\mathbf{9 0 0}}$ & UMTS $_{\mathbf{2 1 0 0}}$ \\
\hline Number of sites & 23,627 & 44,474 \\
\hline NodeB & 23,627 & 44,474 \\
\hline RNC & 150 & 257 \\
\hline
\end{tabular}


TableIII shows access network equipment, their respective unit costs and total costs, CAPEX and OPEX values.

TABLE III. EQUIPMENTS COSTS, CAPEX AND OPEX VALUES

\begin{tabular}{|c|c|c|c|c|c|}
\hline \begin{tabular}{|l|} 
Equipment \\
Type
\end{tabular} & \begin{tabular}{|l|} 
Required \\
number \\
$\left(\right.$ UMTS $\left._{900}\right)$ \\
\end{tabular} & \begin{tabular}{|l|} 
Required \\
number \\
(UMTS $\left._{2100}\right)$
\end{tabular} & $\begin{array}{l}\text { Unit cost, } \\
\$\end{array}$ & \begin{tabular}{|l|} 
Total cost, $\$$ \\
(UMTS $\left._{900}\right)$
\end{tabular} & \begin{tabular}{|l} 
Total cost, $\$$ \\
$\left(\right.$ UMTS $\left._{900}\right)$
\end{tabular} \\
\hline NodeB & 23,627 & 44,474 & 75,000 & $1,772,025,000$ & $3,335,550,000$ \\
\hline \begin{tabular}{|l|} 
NobeB \\
installation \\
\&site \\
acquisition \\
\end{tabular} & Once & Once & 30,000 & 30,000 & 30,000 \\
\hline $\begin{array}{l}\text { NodeB } \\
\text { annual } \\
\text { lease }\end{array}$ & & & 20,000 & 20,000 & 20,000 \\
\hline $\mathrm{RNC}$ & 150 & 257 & $1,000,000$ & 150,0 & $257,000,000$ \\
\hline \begin{tabular}{|l|} 
Spectrum \\
license fee
\end{tabular} & $\begin{array}{l}\text { Once per } \\
\text { year }\end{array}$ & $\begin{array}{l}\text { Once per } \\
\text { year }\end{array}$ & 50 & 50 & 50 \\
\hline $\begin{array}{l}\text { Network } \\
\text { facility } \\
\text { service } \\
\text { operation } \\
\text { fee }\end{array}$ & $\begin{array}{l}\text { Once for } 25 \\
\text { years }\end{array}$ & $\begin{array}{l}\text { Once for } 25 \\
\text { years }\end{array}$ & 200 & 200 & 200 \\
\hline \multicolumn{4}{|c|}{ Capital Expenditure Subtotal } & $1,922,075,250$ & $3,592,600,250$ \\
\hline \multicolumn{3}{|c|}{$\begin{array}{l}\text { Network operational and } \\
\text { maintenance costs (OPEX) }\end{array}$} & \begin{tabular}{|l|}
$20 \%$ of \\
CAPEX \\
per year
\end{tabular} & $384,415,050$ & $718,520,050$ \\
\hline \multicolumn{4}{|c|}{ CAPEX per Annum } & $2,306,490,300$ & $4,311,120,300$ \\
\hline
\end{tabular}

Table IV shows values of NPV for both UMTS900 and UMTS2100 with the assumption that the economic life time is five (5) years.

TABLE IV. VALUES OF NPV FOR UMTS900 AND UMTS2100

\begin{tabular}{|c|r|r|}
\hline \multirow{2}{*}{ Year } & \multicolumn{2}{|c|}{ NPV } \\
\cline { 2 - 3 } & \multicolumn{1}{|c|}{ UMTS $_{\mathbf{9 0 0}}$} & \multicolumn{1}{c|}{ UMTS $_{\mathbf{2 1 0 0}}$} \\
\hline 0 (investment costs) & $-2,306,490,300$ & $-4,311,120,300$ \\
\hline 1 & $-872,681,879$ & -3302536425 \\
\hline 2 & $430,780,321$ & -2385641993 \\
\hline 3 & $1,615,745,958$ & -1552101600 \\
\hline 4 & $2,692,987,446$ & -794337606 \\
\hline 5 & $3,672,297,890$ & $-105,461,248$ \\
\hline 6 & & $520,789,986$ \\
\hline
\end{tabular}

From the definition of payback period, which is a number of years to wait until the accumulated discounted cash flows from the investment equal or exceed the cost of investment (i.e when the NPV turns from negative to positive value), then the payback period for UMTS900 is two (2) years, which implies that an annual cash return of $50 \%$. After five (5) years of investment, the NPV value of UMTS900 connectivity model is positive, which means that the investment will be profitable, hence this investment is the feasible one. On the other hand, payback period of UMTS2100 is six (6) years, implying that the annual cash return for this investment is less than $20 \%$. Its NPV is still negative up to five years, which is the estimated economic lifetime of the investment. The payback period and NPV criteria suggest that UMTS2100 investment is not a feasible option.

Table V shows $57 \%$ and $1 \%$ values of IRR obtained for UMTS900 and UMTS2100, respectively. The calculated value of IRR for UMTS900 is higher than the industrial benchmark of $10 \%$, therefore, UMTS900 has an acceptable value of IRR. The higher value of IRR implies that return of investment will be recouped much faster. On the other hand, the value of IRR for UMTS2100 is 1\%, which is much lower than the industrial benchmark. Based on IRR rule, the UMTS2100 investment is supposed to be rejected.

TABLE V. VALUES OF IRR FOR UMTS900 AND UMTS2100

\begin{tabular}{|l|l|l|}
\hline & UMTS900 & UMTS2100 \\
\hline Year & Cash Flow & Cash Flow \\
\hline 0 & $-2,306,490,300$ & $-4,311,120,300$ \\
\hline 1 & $1,577,189,263$ & $1,109,442,263$ \\
\hline 2 & $1,577,189,263$ & $1,109,442,263$ \\
\hline 3 & $1,577,189,263$ & $1,109,442,263$ \\
\hline 4 & $1,577,189,263$ & $1,109,442,263$ \\
\hline 5 & $1,577,189,263$ & $1,109,442,263$ \\
\hline IRR $=$ & $\mathbf{5 7 \%}$ & $\mathbf{1 \%}$ \\
\hline
\end{tabular}

Table VI summarizes results of sensitivity analysis for UMTS900, which is a feasible connectivity option, at $25 \%$ increase or decrease in either OPEX or CAPEX value.

TABLE VI. SENSITIVITY ANALYSIS RESULTS FOR UMTS900

\begin{tabular}{|c|l|l|l|l|}
\hline SN & $\begin{array}{l}\text { Parameter } \\
\text { changes }\end{array}$ & $\begin{array}{l}\text { New values } \\
\text { changes }\end{array}$ & $\begin{array}{l}\text { New } \\
\text { IRR }\end{array}$ & New NPV \\
\hline 1. & $\begin{array}{l}25 \% \\
\text { increase in CAPEX }\end{array}$ & $\begin{array}{l}57 \% \\
\text { (Original } \\
\text { IRR) }\end{array}$ & $\begin{array}{l}3,672,297,890 \\
\text { (Original } \\
\text { NPV) }\end{array}$ \\
\hline 2. & $\begin{array}{l}25 \% \\
\text { decrease in CAPEX }\end{array}$ & $1,729,867,725$ & $83 \%$ & $3,095,675,316$ \\
\hline 3. & $\begin{array}{l}25 \% \\
\text { increase in OPEX }\end{array}$ & $480,518,813$ & $54 \%$ & $3,417,248,920,466$ \\
\hline 4. & $\begin{array}{l}25 \% \\
\text { decrease in OPEX }\end{array}$ & $288,311,288$ & $61 \%$ & $3,927,314,098$ \\
\hline
\end{tabular}

Results of the sensitivity analysis summarized in Table 5, shows that, neither increase nor decrease of $25 \%$ for both CAPEX and OPEX costs had an effect to the UMTS900 investment. All the new IRRs lie well above the industrial benchmark and the new NPVs are positive. The payback periods are two (2) to three (3) years, while the economic lifetime of the investment is estimated to be five (5) years. Therefore, in this case, the sensitivity analysis suggests that investment in UMTS900 is out of risk even with $25 \%$ forecast errors in capital or operational costs.

\section{CONCLUSION}

This paper provided a comparison between two connectivity models: UMTS 900 and UMTS 2100 by using techno-economic analysis to identify their economic feasibility and a cost-effective option between the two technologies. The 
cost analysis results show that capital and operational costs of UMTS900 connectivity model is cheaper than its counterpart, the UMTS2100. Cost reduction on UMTS900 is due to its implementation strategy of re-using existing GSM network infrastructure. Re-using the existing infrastructure cuts down costs of civil work, site rental, administration and maintenances which will otherwise be required if one has to build a completely new site for UMTS900. Another aspect which brings about cost efficiency on UMTS900 is its wider coverage compared to the coverage achieved by UMTS2100. The UMTS900 operates at lower frequency, $900 \mathrm{MHz}$, hence results into a longer cell radius compared to the cell radius of a high frequency technology, the $2100 \mathrm{MHz}$. This means, the number of sites for UMTS900 needed are fewer than the number of sites for UMTS2100 to cover the same geographical area. Fewer sites implies cost efficiency in the capital expenditure and the opposite is true with more sites for UMTS2100.

Results of the comparison based on techno-economic criteria show that; investment in UMTS900 has a positive NPV and an IRR value within the acceptable range, that is above the industrial benchmark. It's payback period is 2 years implying an annual cash return of 50\%. Furthermore, sensitivity analysis revealed that the investment is still stable within an error margin of $25 \%$ on capital and operational costs. On the other hand, UMTS2100 investment showed negative NPVs within the estimated five years of the investment economic lifetime. It's payback period is six years, which means that, this investment had an annual cash return of less than $20 \%$. The value of internal rate of return is far below the industrial benchmark. Results suggest that UMTS2100 is a non-profitable investment in this case. These results explain why coverage of existing UMTS2100 networks, at least in Tanzania, are urbanbased. That is the UMTS2100 connectivity model is unprofitable, if it is extended to rural areas.

Basing on the techno-economic analysis, this paper concludes that, in order to provide coverage for the whole of Tanzania, a connectivity model built from re-using existing GSM infrastructure to implement $3 \mathrm{G}$ network at $900 \mathrm{MHz}$ technology is a feasible and cost effective option. It is free of risk even at $25 \%$ forecast errors in CAPEX and OPEX. This results can be generalized to other developing country, beacuse rural areas of the developing countries pose more or less similar characteristics with regard to ICT infrastructure development. Therefore, UMTS at $900 \mathrm{MHz}$ frequency band is a connectivity solution with the potentials to provide broadband access network to the underserved community especially rural areas of the developing countries.

\section{ACKNOWLEDGMENT}

Authors appreciate the Swedish International Development Cooperation Agency (Sida) for financial generosity in this study.

\section{REFERENCES}

[1] UMTS-Forum, "HSPA broadband services in the $900 \mathrm{MHz}$ band: Strategy and Deployment," White Paper prepared by UMTS Forum, 2009.

[2] Nokia Siemens Networks, "WCDMA Frequency Refarming : A Leap Forward Towards Ubiquitous Mobile Broadband Coverage," White Paper prepared by Nokia Siemens Networks, 2010.
[3] GSA, "UMTS900 Global Status," Report submitted to the Global mobile Suppliers Association., 2011.

[4] H. Holma and A. Toskala, WCDMA for UMTS: Radio Access for Third Generation Mobile Communications, John Wiley \& Sons, Ltd, 2004.

[5] J. Laiho, A. Wacker, and T. s` Novosad, Radio Network Planning and Optimisation for UMTS, John Wiley \& Sons Ltd, 2006.

[6] K.R. Chevallier, C., Brunner, C., Garavaglia, A., Murray, K.P and Baker, WCDMA (UMTS) Deployment Handbook: Planning and Optimization Aspects., John Wiley \& Sons Ltd, 2006.

[7] Ovum-Consulting, "Market Study for UMTS900," $A$ report to GSMA. Project Number CLW28 Version- V1.1, vol. 44, 2007, pp. 1 - 144.

[8] V.S. Abhayawardhana, I.J. Wassell, D. Crosby, M.P. Sellars, and M.G. Brown, "Comparison of Empirical Propagation Path Loss Models for Fixed Wireless Access Systems," Proceedings of Vehicular Technology Conference, 2005. VTC 2005-Spring., vol. 1, 2005, pp. 7377.

[9] V. Kamboj, D.K. Gupta, and N. Birla, "Comparison of Path Loss Models For WiMAX in Rural Environment at $3.5 \mathrm{GHz}$," International Journal of Engineering Science and Technology (IJEST), vol. 3, 2011, pp. 1432-1437.

[10] S. Ranvier, "Path Loss Models," S-72.333 Physical layer methods in wireless communication systems. Teaching Notes. SMARAD Centre of Excellence, Helsinki University of Technology, Finland, vol. 5, Dec. 2006, pp. 152-154.

[11] TCRA-Statistics, "Report on Internet and Data Services In Tanzania: A Supply-Side Survey," Quarterly Telecom Statistics. Quarter 2 (December 2010) Report by Tanzania Communication Regulatory Authority (TCRA), 2010.

[12] Ross et al., Fundamentals of Corporate Finance, McGraw- Hill Companies, Inc., 2000.

[13] TCRA-fees, "Schedule of License Categories and Fees," Issued by Tanzania Communications Regulatory Authority, 2010.

[14] J.A. White, Principles of Engineering Economic Analysis, Wiley, New York, 1977.

[15] W. Park, Cost Engineering Analysis: A Guide to the Economic Evaluation of Engineering Projects, Wiley, New York, 1973.

[16] TRA, “The Income Tax Act, 2004," Tanzania Revenue Authority Income Tax Document., 2004. 